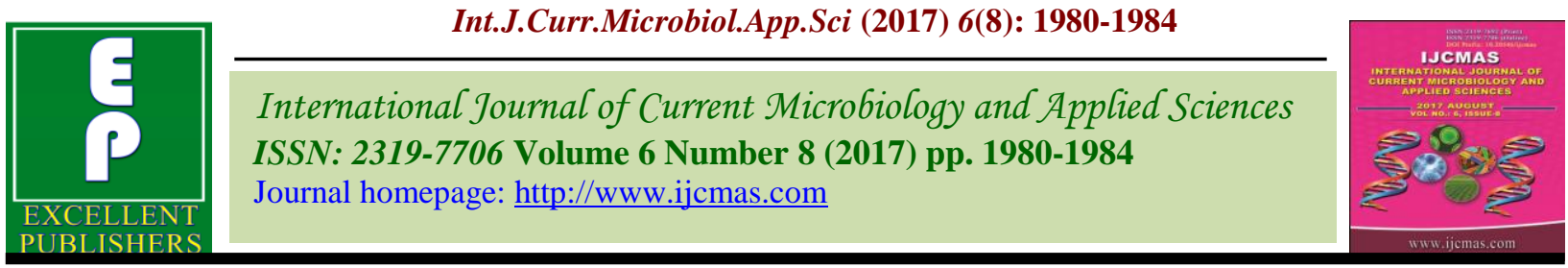

Original Research Article

https://doi.org/10.20546/ijcmas.2017.608.235

\title{
Efficacy of Different Bio Control Agents against Meloidogyne incognita and Fusarium oxysporum on Tomato
}

\author{
Naresh Kumar*, Jayant Bhatt, Ratan Lal Sharma and Prahlad \\ Department of Plant Pathology, College of Agriculture, Jawaharlal Nehru Krishi Vishwa \\ Vidyalaya Jabalpur, MP- 482004, India \\ *Corresponding author
}

\section{A B S T R A C T}

Keywords

Fusarium oxysporum, Meloidogyne incognita, Bio control agents.

Article Info

Accepted:

19 June 2017

Available Online:

10 August 2017
Biological control is considered as new efficient method that becomes widely used for controlling plant parasitic nematodes, as aim to decrease the extent of environment degradation and the effect of the excessive toxic nematicides. So, this study was done to investigate the role of some bacterial genera as biocontrol agent against Meloidogyne incognita. The results of in pot house experiments indicated that, all tested bacteria have a greatly significant effectiveness for suppressing $M$. incognita. Pot house results showed that significantly increased $(80.32 \mathrm{~cm})$ plant height was recorded with Pacilomyces lilacinus followed by Bacillus subtilis (72.23 $\mathrm{cm}), T$. harzianum $(68.77 \mathrm{~cm})$ and $P$. chlamydosporia $(64.52 \mathrm{~cm})$ over control. The effects of $T$. viride, $T$. harzianum and Pacilomyces lilacinus tills were though non-significant but superior over control $(52.54 \mathrm{~cm})$. Maximum root length $(20.67 \mathrm{~cm})$ was recorded with Pacilomyces lilacinus followed by Bacillus subtilis $(17.63 \mathrm{~cm})$ and T. harzianum $(14.67 \mathrm{~cm})$.

\section{Introduction}

Tomato (Solanum lycopersicum L.) is one of the most popular vegetable crops grown in the world, next to potato. It is used as a fresh vegetable and also can be processed and canned as a paste, juice, sauce, powder or as a whole (Barone and Frusciante, 2007). The ripe fruits are good source of vitamin $\mathrm{A}, \mathrm{B}$ and $\mathrm{C}$ which add wide varieties of colour and flavour to the food. Recently, it started gaining more medicinal value because of the antioxidant property of ascorbic acid and lycopene content (Anon, 2002). Tomatoes are parasitized by a number of pathogens, including Fusarim oxysporium f. sp. lycopersici (Sacc. W.C. Snyder et al., 2003), the causal agent of fusarium wilt, is one of the most important pathogen of tomato (Jones et al., 1982). Due to high temperature and humidity, Fusarium oxysporum f. sp. lycopersici can cause significant damage. Fusarium oxysporum f. sp. lycopersici is soil borne pathogen which can persist for many years in the soil without host. Most infections originate from the population associated with infected tomato debris. Healthy plants can become infected by Fusarium oxysporum if the soil, is infested with the pathogen (Farr et al., 1989). Browning of the vascular tissue is 
strong evidence of Fusarium wilt (Snyder and Hans, 2003). The Root knot nematode, Meloidogyne Incognita is important pest of vegetables in subtropical and tropical climates including India and inflicts significant yield losses (Akram and Khan, 2006). Meloidogyne incognita is the most dominant species accounting for 64 per cent of total population which is widely prevalent inflicting serious loss to tomato fruit yield (Sasser, 1980). The fungus also develops synergistic relationship with Meloidogyne species leading to root-knot wilt disease complex (Patel et al., 2000).

\section{Materials and Methods}

The experiment was conducted in ten $\mathrm{cm}$ earthen pots containing $500 \mathrm{~cm}$ sterilized soil employing six bio-control agents viz, Trichoderma viride, Trichoderma harzianum, Paecilomyces lilacinus, Pseudomonas fluorescence, Bacillus subtilis, and Pochonia chlamydosporia were used in present studies. The fungus $P$. lilacinus and Trichoderma viride were isolated from the soils of J.N.KV.V Jabalpur farm by sprinkling it on Petri plates containing sterilized Potato Dextrose Agar (PDA) medium. Both the organism were purified and maintained on PDA plants. The fungus $T$. viride was multiplied on wheat seeds. The seeds were boiled in water for half an hour and excess moisture was drained out The boiled seeds of wheat were filled in polypropylene bags @ $500 \mathrm{~g}$ seeds per bag and autoclaved at $1.05 \mathrm{~kg} /$ $\mathrm{cm}^{2}$ for 20 minutes. After cooling the bags were inoculated with pure culture of $T$. viride and incubated at $24^{\circ} \mathrm{C}$ for 10 days. When sufficient growth was achieved the seeds along with fungus were mixed with the pot soil $2 \mathrm{~g} /$ pot. Before mixing the fungus spore load was determined by haemocytometer. Similarly the fungus $P$. lilacinus was also isolated from the soil of J.N.K.V.V Jabalpur which was mass multiplied on wheat seeds following the technique described earlier and at maximum growth spore load mixed with the pot soil @ 2 g per pot. Commercial formulations of Pochonia chlamydosporia, Pseudomonas fluorescence and Bacillus subtilis were obtained from Department of Nematology, Tamil Nadu Agricultural University with a spore load 2 x 107/g soil colony forming units (CFU). These formulations were mixed with the pot soil @ $2 \mathrm{~g} /$ pot. After mixing the test bio agents in to the soil infested with Fusarium oxysporum the pot soil was sprayed by freshly hatched and surface sterilized second stage juveniles of $M$. incognita. The population of root-knot nematode ( $2 \mathrm{~h} / \mathrm{g}$ soil) was determined by using method as described earlier. The soil with test bio agents and $M$. incognita was filled in ten $\mathrm{cm}$ earthen pots and sown with tomato seedling. Each treatment was replicated five times and randomized on glass house bench. The experiment was terminated 45 days after inoculation and observations on plant height, root length, shoot weight (fresh and dry), root weight (fresh and dry), number of galls, number of egg masses were recorded.

\section{Results and Discussion}

The pot experiment on the management of $M$. incognita and $F$. oxsysporum a disease complex was conducted under glass house conditions and the data is presented in the table 1. The data indicated that significantly increased $(80.32 \mathrm{~cm})$ plant height was recorded with Pacilomyces lilacinus followed by Bacillus subtilis $(72.23 \mathrm{~cm}), T$. harzianum $(68.77 \mathrm{~cm})$ and $P$. chlamydosporia $(64.52 \mathrm{~cm})$ over control. The effects of $T$. viride, $T$. harzianum and Pacilomyces lilacinus tills were though non-significant but superior over control $(52.54 \mathrm{~cm})$. Maximum root length (20.67 cm) was recorded with Pacilomyces lilaceous followed by Bacillus subtilis (17.63 $\mathrm{cm})$ and $T$. harzianum $(14.67 \mathrm{~cm})$. Rest of the treatment were observed to be inferior to Pacilomyces lilacinus but significantly 
superior over control $(11.47 \mathrm{~cm})$. On fresh weight basis maximum shoot weight $(8.12 \mathrm{~g})$ was recorded with Pacilomyces lilacinus followed by Bacillus subtilis (7.60 g), T. harzianum $(5.79 \mathrm{~g})$ and $P$. chlamydosporia $(5.48 \mathrm{~g})$. These treatments were significantly superior over rest of the treatments and control (3.08 g). Similar trend was noted with fresh weight of root where Pacilomyces lilacinus showed its efficacy over control and rest of the treatments. The root weight in this treatment was noted to be $0.69 \mathrm{~g}$. The effect of Pacilomyces lilacinus and Bacillus subtilis remained at par but significantly superior over control $(0.47 \mathrm{~g})$.

Similarly on dry weight basis maximum $(0.77$ g) shoot weight was recorded with Pacilomyces lilacinus which was significantly superior over rest of the treatments and control $(0.41 \mathrm{~g})$. Dry weight of root showed similar results where maximum $(0.26 \mathrm{~g})$ root weight was noted with Paecilomyces lilacinus followed by Bacillus subtilis (0.24 g), $T$. harzianum $(0.18 \mathrm{~g})$ and $P$. chlamydosporia $(0.17 \mathrm{~g})$. Minimum weight was recorded with control $(0.11 \mathrm{~g})$.

Number of galls was significantly and drastically reduced in Paecilomyces lilacinus (12.80) as against control where maximum (38.33) galls were recorded. Bacillus subtilis recorded 18.14, T. Harzianum (24.11) and $P$. chlamydosporia (25.84) galls per plant on an average basis. Rest of the treatments were inferior over these but superior over control. Minimum egg masses/gall (19.35) were noted with Paecilomyces lilacinus followed by Bacillus subtilis (20.56) against maximum egg masses (34.13) in control. Rest of the treatments were inferior over these but superior over control.

The data presented in the table indicated that Paecolomycs liIacinus significantly increased the growth parameters of the tomato viz., plant height, root length, fresh and dry weight of shoot and roots with significant decreases in the number of galls and final nematode population.these result are in accord with the finding of Latha et al., (2000) who observed increase in growth parameters and decrease in nematode multiplication of Hetrodera cajeni in presence of Macrophomina phaseolina on Vigna mungo. Similar result has also been observed by Verma et al., (2005). P. lilacinus has been reported to produce peptidal antibiotic viz; lilacin and paecilotixin that are toxic to nematode (Verma et al., 2005)

Bacillus subtilis and T. harzianum showed its efficacy in reducing the nematode galling and enhancing the growth characters of the tomato. These findings have also been supported by the result shown by Siddiqui and Mohmood (1995) on chickpea with M.incoginita and M. Phaseolina, Poornima et al., (2007) on banana with Fusarium oxysporum and Helicotylenchus multicinctus. Sharon et al., 2001 reported that Trichoderma harzianum reduced galling of root-knot nematode Meloidogyne javanica on tomato plants. Spiegel and Chet (1998) used different Trichoderma isolates against the root knot nematode $M$. javanica, and the results showed that a decrease in root galling index as well as eggs per gram of root.

In conclusion, Paecilomyces lilacinus significantly increased the growth of the tomato Viz., plant height, root length, fresh and dry weight of shoot and roots with significant decreases in the number of galls and final nematode population. Bacillus subtilis was also noted to be superior and took second rank in improving the plant growth and reduced nematode population. The nemato pathogenic fungus Paecelomyces liIacinus and Bacillus subtilis were found to have a significant effect in reducing galls and enhancing plant growth. 
Table.1 Efficacy of different bio control agents against Meloidogyne incognita and

Fusarium oxysporum f. sp. Lycpersici on plant growth parameters

\begin{tabular}{|c|c|c|c|c|c|c|c|c|c|}
\hline \multirow{2}{*}{$\begin{array}{l}\text { S. } \\
\text { No. }\end{array}$} & \multirow{2}{*}{ Treatments } & \multirow{2}{*}{$\begin{array}{l}\text { Plant } \\
\text { Height } \\
\text { (cm) }\end{array}$} & \multirow{2}{*}{$\begin{array}{l}\text { Root } \\
\text { Length } \\
\text { (cm) }\end{array}$} & \multicolumn{2}{|c|}{ Fresh weight (g) } & \multicolumn{2}{|c|}{ Dry weight (g) } & \multirow{2}{*}{$\begin{array}{l}\text { No of Galls/ } \\
\text { Plant }\end{array}$} & \multirow{2}{*}{$\begin{array}{l}\text { No of egg } \\
\text { Mass/plan }\end{array}$} \\
\hline & & & & Shoot & Root & Shoot & Root & & \\
\hline 1 & Bacillus subtilis & 72.23 & 17.63 & 7.60 & 0.67 & 0.74 & 0.24 & 18.14 & 20.56 \\
\hline 2 & Pochonia chlamydosporia & 64.52 & 13.70 & 5.48 & 0.62 & 0.57 & 0.17 & 25.84 & 24.24 \\
\hline 3 & Trichoderma harzianum & 68.77 & 14.67 & 5.79 & 0.65 & 0.63 & 0.18 & 24.11 & 21.65 \\
\hline 4 & Trichoderma viride & 60.05 & 13.70 & 4.15 & 0.61 & 0.56 & 0.13 & 29.70 & 28.22 \\
\hline 5 & Paecilomyces lilacinus & 80.32 & 20.67 & 8.12 & 0.69 & 0.77 & 0.26 & 12.80 & 19.35 \\
\hline 6 & Control & 52.54 & 11.47 & 3.08 & 0.47 & 0.41 & 0.11 & 38.33 & 34.13 \\
\hline & $\mathrm{S} . \mathrm{E}(\mathrm{m}) \pm$ & 1.12 & 1.36 & 1.05 & 0.01 & 0.04 & 0.01 & 1.37 & 1.62 \\
\hline & $\mathrm{CD}$ at $5 \%$ & 3.492 & 4.237 & 3.294 & 0.038 & 0.152 & 0.36 & 4.292 & 5.048 \\
\hline
\end{tabular}




\section{Acknowledgement}

The authors are thankful to the Dean, College of Agriculture, Jawaharlal Nehru Krishi Vishwa Vidyalaya Jabalpur for providing necessary facilities and permission to conduct the study.

\section{References}

Anonymous. 2002. Asian Vegetable Research Development, Taiwan, Annual Report, pp. 110.

Akram MA and Khan MR. 2006. Interaction of Meloidogyne incognita and Fusarium oxysporum f.sp. Lycopersici on tomato. Annual Plant Protection Science 14 (2): 448-451.

Barone A and Frusciante L. 2007. Molecular marker assisted selection for resistance to pathogens in tomato, MarkerAssisted Selection, current status and future perspectives in crops, livestock, forestry and fish 153-164.

Farr DF, Bills GF, Chamuris GP and Rossman AY.1989. Fungi on Plants and Plant Products in the United States. APS PRESS: St. Paul, USA. Pp 1-1252.

Jones JP, Jones JB and Miller W. 1982. Fusarium wilt on tomato.Department Agriculture \& Consumer Service, Division of plant Industry. Plant Pathology Circular No.237.

Latha TKS, Rajeswari EV and Narasimhan. 2000. Management of root-rot disease complex through antagonists and chemicals. Indian Phytopathology: 2000.53 (2): 216-218.

Poornima K, Angappan K, Kannan R, Kumar $\mathrm{N}$ and Balanoha TN. 2007. Interaction of nematodes with the fungal Panama wilt disease of banana and its management. Nematology Mediterranea 35 (1): 35-39.

Patel DB, Patel DJ and Patel NB. 2000. Interaction of semiform nematode and Fusarium oxysporum f. sp. lycopersici in tomato. Annual Plant Protection Science, 8: 209-211.

Sasser JN.1980. Root-knot nematode a global menace to crop production. Plant Disease, 64: 36-41.

Sharon,E., Bar-Eyal,M.,Chet,I., HerreraEstrella,A., Kleifeld,O. and Spiegel,y.,(2001) Biological Control of the Root-Knot Nematode Meloidogyne javanica by Trichoderma harzianum. Phytopathology. 2001 Jul; 91(7):68793.

Siddiqui ZA, Mahmood I. 1995. Management of Meloidogyne incognita race 3 and Macrophomina phaseolina by fungus culture filtrates and Bacillus subtilis in chickpea. Fundamental and Applied Nematology 18 (1): 71-76.

Snyder WC and Hans HN. 2003. Fusarium oxysporum f. sp lycopersici (Sacc.) and Prepared by Mui-Yun Wong Soil borne Plant Pathogen Class Project, spring. PP 728.

Spiegel Y and Chet I. 1998. Evaluation of Trichoderma spp. As a biocontrol agent against soilborne fungi and plant parasitic nematodes in Isral. Integer. Pest Managment Reviw 3: 169-175.

Verma AC, Sing HK and Nehal KM. 2005. Managment of root knot nematode, Meloidogyne incognita through antagonistic approaches in pointed gourd. Indian Journal Nematology 35 (1): 78-79.

\section{How to cite this article:}

Naresh Kumar, Jayant Bhatt, Ratan Lal Sharma and Prahlad. 2017. Efficacy of Different Bio Control Agents against Meloidogyne Incognita and Fusarium Oxysporum on Tomato. Int.J.Curr.Microbiol.App.Sci. 6(8): 1980-1984. doi: https://doi.org/10.20546/ijcmas.2017.608.235 